\title{
THE INFLUENCE OF INSTITUTIONS IN FOUNDER-CEO RETENTION: IPO FIRMS IN A DEVELOPING COUNTRY CONTEXT
}

\author{
Bruce Hearn* \\ University of Leicester \\ Jenifer Piesse \\ Bournemouth University, UK \\ and University of Stellenbosch, South Africa
}

\begin{abstract}
While there are considerable advantages for firms in the early stages of their lifecycles in having their entrepreneurial founders in leading CEO position these change during the initial primary offering (IPO) process and attraction of new minority outsider investors. As such the new firm-level corporate governance mechanisms as well as larger state-level institutional characteristics exert considerable influence in governance, incentive alignment and reduction of agency between entrepreneurial founder CEO and new outsider shareholders. Using a unique hand-collected sample of 97 IPO firms from across 18 Sub Saharan African (SSA) stock markets we find evidence that IPO firms are more likely to have founders as CEO with boards characterised by fewer foreign directors, fewer nonexecutives and greater proportions of these being independent and less ownership by nonexecutives. Additionally lower government effectiveness and weaker rule of law are associated with founding entrepreneur being retained as CEO while the opposite is true of informational environment quality, including corruption control and unrestricted media.
\end{abstract}

Keywords: IPO; Founder-CEOs; Institutions; Entrepreneurship

* Corresponding author: School of Management, Ken-Edwards Building, University of Leicester, Leicester. UK. LE1 7RH. Tel: 44(0)116 252 5141. Email: bruce.hearn@le.ac.uk

\section{Acknowledgements}

We are grateful to Lilian de Menezes for Portuguese to English translation of prospectuses from Cape Verde Islands and Mozambique and to Nadia Oumalik and Olive Kone for assistance with French translation of prospectuses from BRVM (Cote d'Ivoire) and Cameroon. 


\section{THE INFLUENCE OF INSTITUTIONS IN FOUNDER-CEO RETENTION: IPO FIRMS IN A DEVELOPING COUNTRY CONTEXT}

\section{Introduction}

The Initial Primary Offering (IPO) diversifies ownership to outsider minority investors and is a key milestone for the entrepreneurial firm. The consequent change in organisational structure involves implementing new governance mechanisms, including informational transparency, and is often associated with a new managerial team that comprises individuals that are better suited to a public listed firm. But, this frequently moves the firm away from its entrepreneurial origins to a more professional management style and the resulting agency relationships associated with a separation of ownership and control (Jain and Tabak, 2008; Gao and Jain, 2011).

One of the major questions at this time is the role of CEO, and in particular, whether the founder is retained or a new CEO is appointed to this primary leadership role (Jain and Tabak, 2008). Considerable attention has been given in the literature to CEO succession. However, the issue of CEO succession following IPO and the impact of institutions in this decision has been largely ignored in the entrepreneurship literature. Furthermore, research on CEO succession has been largely limited to developed market economies. Thus, the contribution of this paper is to examine factors that determine CEO retention following IPO using data from developing and emerging countries.

The role of the CEO in an entrepreneurial venture differs hugely from that in a newly listed firm and this is characterised by the need for a very different set of skills and activities (Audretsch et al, 2009; Certo et al, 2001; Gao and Jain, 2011). At the early stage of a new venture, entrepreneurs play a major role by providing competitive advantage through knowledge and human capital, which Audretsch et al (2009) find to be intrinsically linked to the capital resources of the firm. This strategic entrepreneurship requires a set of opportunity-seeking behaviours (entrepreneurship) and an advantage-seeking nature (management and coordination of resources) (Ireland et al, 2003). Innovation in this context is largely confined to creating and assimilating new technologies to gain competitive advantage in product markets and earn entrepreneurial rents (in the spirit of Shumpeter (1934)) or make changes in the production process, organizational structure or business model that create greater efficiencies (Audretsch et al, 2009). Success for early stage ventures rests on a complex interaction of the personal characteristics of the founder, such as age, experience and education (Naude et al, 2008), the extent of their social networks (Rotefoss and Kolvereid, 2005) and an clear knowledge of the business (Dollinger, 1995). Externally, environmental factors need to be considered as firms are required to enter into transactional relationships with outside agents as not all resources can be generated internally (Bouchikhi, 1993).

Audretsch et al (2009) argue that strategic entrepreneurship and consequent wealth generation occurs through the intersection of three key behaviours: the leadership capabilities and human capital 
of individuals; the operational structure, collective mindset and culture within firms; and the means to create advantage by acquiring resources and new market opportunities external to the firm. The human capital of an individual founder-manager in entrepreneurial ventures is then combined with a degree of diversified ownership linked to early stage investors, such as business angels and venture capitalists (Mason and Harrison, 1996, 2002; Alhorr et al, 2008). This requires a multiple agency framework to understand the interrelationships that exist in early-stage ventures (Arthurs et al, 2008). This is necessary to examine the relative bargaining positions in terms of ownership by the various principals compared with the individuals controlling the intangible knowledge and human capital assets. In particular, this requires a greater understanding of board composition and structure, the levels of co-ownership amongst directors and the retention of the founder-CEO. This group are also influenced by the venture capitalists, who are themselves subject to conflicting priorities and investment time horizons (Arthurs et al, 2008). Thus, the paper extends the analysis by Jain and Tabak (2008) and Audretsch et al (2009), who apply an agency perspective focussed on the the CEO as shirking and appropriating assets but ignore founder-entrepreneurs that exhibit longer-term nonpecuniary motivations and enhance firm value and hence mitigate agency costs (Arthurs and Busenitz, 2003). Rather, this paper acknowledges the varying investment time horizons of the internal and external principals and their different incentives.

The concept of the firm as a nexus of contractual relationships (Jensen and Meckling, 1976), subject to transactions costs through the idea of bounded rationality (Williamson, 2000), requires established institutions and sound systems of governance (Williamson, 2002). This view of the firm as a complex network with emphasis on social capital is found in studies of early-stage entrepreneurial ventures in rural Italy by Meccheri and Pelloni (2006) who argue that the entrepreneurship literature emphases strategic advantage based on human resource factors while ignoring the founders' social capital. This ability gain advantage from social structures, networks and ties (Bourdieu, 1983; Portes, 1998) is critical in using social links to enable the exploitation of new opportunities and to identify and access scarce resources (Green and Brown, 1997).

However, it is necessary to consider the institutions that affect the founder-entrepreneur. National legal, political and governance systems all influence the structure of the domestic business environment and are an essential determinant in the entrepreneur's ability to secure financial resources (Zhang and Wong, 2008). Thus, theory suggests that the entrepreneur's use of social network is a solution to market-failure in risky capital markets (Shane and Cable, 2002). Further, while institutional quality influences the development of financial markets and thus the extent of the choice of financing decisions of entrepreneurial firms, regulatory frameworks (Jeng and Wells, 2000; Megginson, 2004), legal systems, particularly with respect to bankruptcy (Armour and Cummings, 2006) and social and cultural factors that affect private sector development (Wright et al, 2005) all stimulate growth and entrepreneurship (Alhorr et al, 2008). Cross country differences in institutional 
development may also impact cognitive aspects of entrepreneurial thinking (Alhorr et al, 2008), which again are associated with transactions costs (North, 1989). Mitchell et al (2002: p 97) define entrepreneurial cognitions as being "the knowledge structures that people use to make assessments, judgements, or decisions involving opportunity evaluation, venture creation, and growth". The institutional environment determines the extent to which social networks underpin the business environment and how important these are to entrepreneurs in providing valuable information and resources.

However, while several studies have investigated the institutional determinants of early-stage angel and venture capital fund raising by entrepreneurs in a number of countries, the impact on founder-CEO retention following IPO has been largely ignored. This is an important issue as the retention of founder-entrepreneurs has a significant effect on the structure of the wider business community due to the distinctive characteristics, social networks and reputation of these individuals (Zhang and Wong, 2008). This is particularly the case in developing and emerging economies where much of the entrepreneurial is in the formal sector (Bradford, 2007) and encouraging founderentrepreneurs are at the centre of development strategy (Naude et al, 2008). This is especially the case in Sub Saharan Africa (SSA) where economic policy reflects that in industrialised countries by promoting a market economy and encourages firms to earn economic rents from comparative advantage and liberalised trade (Ireland et al, 2003). Unfortunately, SSA region has some of the highest regional variation in terms of the quality of institutions, for example, Botswana and Mauritius have levels of transparency comparable to Western Europe while Cote d'Ivoire and Nigeria are amongst the least developed (Transparency International, 2011).

This paper addresses these differences in institutional quality and examines the impact on entrepreneurship in SSA with a specific focus on the retention of the founder-CEO following IPO. Institutional quality is measured using the World Bank Governance indicators developed by Kaufman et al (2009) including: control of corruption, government effectiveness, political stability, regulation, rule of law and voice and accountability. The models are tested on a sample of 96 IPO firms from 14 countries in SSA that obtained a stock exchange listing between 2000 and 2010. The next section discusses the theoretical foundations for the hypotheses tested. Section 3 describes the data and methods. Section 4 presents the result that entrepreneurial founders are more likely to be retained as CEO where internal governance supports their controlling position on the board and there are few foreign and nonexecutive director owners. Industrial effects are important as is early financial support from business angels rather than venture capitalists. The section discusses the role of external governance in the form of national institutions and emphasises the importance of transparency and lower levels of corruption associated with a retained entrepreneurial founder-CEO compared with the rule of law and government effectiveness that suggests the appointment of a professional manager in the senior leadership role. Section 5 concludes. 


\section{Theory and Hypotheses}

The establishment of new ventures by entrepreneurs is closely linked to economic development policy and the efficient integration of resources that is essential to well functioning competitive markets. This is embodied in the concept of strategic entrepreneurship and combines opportunityseeking behaviours, competitive advantage and the innate capabilities of the entrepreneur, such as human and social. Together, these factors link the founder-entrepreneur to the new venture to create a competitive advantage and allow value creation and generation of economic rents.

However, this can also represent a source of vulnerability as the firm develops (Arthurs et al, 2008). This vulnerability can arise from external stakeholders, for example, principals entering the organisational structure for the first time of a firm that has previously relied on the founders for human and social capital (Audretsch et al, 2009; Arthurs et al, 2008). Coff et al (1999) argue that when competitive advantage is wholly reliant on individuals and their idiosyncratic human, reputational and social networks then these founder-entrepreneurs have enhanced bargaining power in negotiating ownership of a greater portion of the wealth they generate for the firm. Their negotiating position is even stronger within the firm where the replacement cost to the organization that would be incurred should they exit is high (Coff and Lee, 2003). Another aspect of firm vulnerability to the founder-entrepreneur is the process of wealth generation within the new venture. Ireland et al (2003) argue that "In general, effective growth is expected to help firms create wealth by building economies of scale as well as market power. These outcomes provide additional resources and contribute to achieving a competitive advantage. Likewise, additional wealth makes it possible for firms to allocate resources to stimulate further growth. This relationship is especially critical to new venture firms - firms that often create wealth by growing rapidly" (p 964)

Arthurs et al (2008) argue this reliance by the firm on key individuals, which may also be a vulnerability, generates two issues for early-stage investors: the first is a desire to see continuity of the founder-entrepreneur in a leadership position given their value-enhancing role while the second supports the introduction of governance mechanisms to align the interests of the founder with those of external owners or principals. These questions merit further research. Arthurs and Busenitz (2003) examine the limitations of agency and stewardship theory in the venture capitalist - entrepreneurfounder relationship. They find that a major limitation of agency theory is the inability to capture the positive motivations of entrepreneur-founders rather than the negative risk arising shirking or various forms of opportunism. Also ignored is the considerable non-financial contribution to the new venture by the founder-entrepreneur that enhances psychological ownership of founder in the venture (Arthurs and Busenitz, 2003). Agency theory fails to account for these additional assets and focuses on reduced valuation due to agency costs (Jensen and Meckling, 1976). 
Thus, the unbalanced treatment of the agency relationship results in an emphasis on negative costs rather than positive benefits. This is compounded when a multiple agency perspective fails to consider the difference between internal principals with a longer time horizon, for example, founderentrepreneurs and business angels (Mason and Harrison, 1996; Harrison et al, 2010), and external principals with shorter time horizons, such as venture capitalists and shareholders (Arthurs et al, 2008). Thus, arguments are developed and hypotheses constructed to test the relationship between internal firm-level board governance mechanisms and founder-CEO succession.

Thus far, the governance mechanisms are assumed to be internal to the firm. However, national institutions can also enhance our understanding of external factors that influence the structure of the economic and business environment and the impact on founder-CEO succession. The quality of institutions is important to the growth and development of financial markets and particularly access to external finance for publically listed firms (Demirguc-Kunt and Maksimovic, 1998) and private enterprises (Payne et al, 2008). Institutions affect the level of protection for minority shareholders (La Porta et al, 2000, 2002) and restrict appropriation of the private benefits of control by insider groups (Doidge et al, 2007). North $(1989,1990)$ claims that the path of economic development is shaped by institutions early in the nation's history and in many developing countries the system of legal and political governance is a legacy of earlier colonial domination. For example, the governance model in Latin America was influenced by Spanish and Portuguese political, legal and governmental bureaucracy (North, 1989) and the structural rigidities this entailed, while in Asia, it was reflected German and English systems (La Porta et al, 2008).

Sub Saharan Africa was largely divided between English and French colonial systems (Joireman, 2001) and not surprisingly this was retained following independence, despite the nature of the institutions being based on somewhat archaic European governance models that supported the control of the population and the exploitation of the extractive industry, with little protection of minority shareholders (Joireman, 2001). This resulted in the adoption of a model of political economy in which social elites dominated local jurisdictions and allowed the appropriation of the private benefits of control at the state level and an inherent unwillingness to change anything that would lead to a reduction in social status or their ability to engage in rent seeking activity (North, 1989).

Once established, institutions become deeply entrenched in societal and cultural norms. These structural rigidities create bottlenecks in development and economic and have an impact on technology accumulation, innovation and the entrepreneurial environment, which in turn affects competition in the long term (North, 1990). Institutional quality also has a pervasive effect on transactions costs, which influences the choices founder-entrepreneurs, for example, social networks become preferable to market mechanisms as a source of information and other resources that are necessary for early-stage ventures. These transactions costs also influence the granting of contracts 
and financing arrangements, making business angel more easily accessible than formal venture capitalists for funding (Zhang and Wong, 2008). To capture the impact of institutional quality on founder-CEO succession following IPO hypotheses are constructed for the World Bank Governance institutional quality indices (Kaufman et al, 2009) to test the relationship between external governance mechanisms and founder-CEO succession.

\subsection{Internal Governance Mechanisms: The Impact of the board on founder-CEO retention}

The international corporate governance literature considers the IPO as the first major liquidity event in the life cycle of new firms when the owners, both founders and initial investors, begin to realise the value of their stake in the firm (Brav and Gompers, 2003). However, a number of potential agency conflicts also arise, particularly where the success of the firm is dependent on key individuals such as the founder-entrepreneur (Bruton et al, 2009). Thus, the question of whether the founder is retained as CEO post-IPO is likely to be determined by the relative negotiating power between the principals. In this situation the structure and composition of the board is an internal governance mechanism to minimise agency costs and ensure incentives are properly aligned to act as an effective monitoring device. Oxelheim and Randoy (2005) suggest that foreign directors are essential for improved firm valuation and are better able to handle complex environments than their domestic counterparts and can introduce international best practice in corporate governance. In the SSA context of this paper, these practices are most likely to be based on Anglo-Saxon shareholder value or European stakeholder models, which in both cases include the protection of minority shareholder property rights and informational transparency, and tend to be representative of (primarily foreign) blockshareholder interests. Given the conflicting priorities between foreign directors and the retention of the founder-entrepreneur as CEO following IPO we test the following hypothesis:

Hypothesis 1. The ratio of foreign to total directors on the board is negatively associated with retention of the probability of founder-entrepreneur as CEO following IPO

The composition of the board in terms of those directors with socially elevated positions in the indigenous society (social elites) may be influential in terms of their relationship with the founderentrepreneur. For example, those with positions in the military, government, politics or academia, are likely to share the same incentives as the founder and have a common interest in the longer-term investment strategies of the firm. Thus, the literature finds a link between entrepreneurial activity and higher levels of human capital such as education (see Ucbarasan et al, 2003 and Maxwell and Levesque, 2011 for examples). Given the history of political economies dominated by social elites in developing economies discussed by North $(1989,1990)$ these individuals tend to benefit from more education and are better able to engage in entrepreneurial activity either on their own behalf or in 
support of their peers. Further evidence for the relationship between social elites on the board and the retention of founder as CEO is Certo et al (2001), who argue that insider dominated boards are more important to the support of the founder-entrepreneur and provides strategic direction for the venture while monitoring and oversight from outsiders on the board are more relevant later in the lifecycle of the firm when professional managers are in engaged (Baysinger and Hoskisson, 1990; Zahra, 1996). Thus, we test the following hypothesis:

Hypothesis 2. The ratio of domestic social elites to total directors on the board is positively associated with probability of the founder-entrepreneur as CEO following IPO.

All directors are bound by a common obligation to fiduciary duty. The role of nonexecutive directors is primarily to monitor the decisions of the executives on the board and protect shareholder interests and there is a large literature to support this (for example, Boyd, 1994; Kosnik, 1990; Zajac and Westphal, 1994; Conyon and Peck, 1998), how less research has focussed on the role of wholly independent nonexecutives. Westphal and Zajac (1995) raise doubts about the actual degree of independence of nonexecutives given the appointment of such individuals is largely a function of the networks enjoyed by the CEO and dominant insiders and the lack of financial reward is hardly an incentive for effective monitoring (Conyon and Peck, 1998). A further issue that is generally neglected is the ineffectiveness of nonexecutives and their ability to act credibly against dominant insider groups that result from a lack of recognition by formal and informal institutions. Therefore, it is reasonable to assume that the presence of non-executive directors is associated with the founderentrepreneur is retained as CEO and thus we test the following hypothesis:

Hypothesis 3. The ratio of wholly independent nonexecutives to total directors on the board is positively associated with the probability of the founder-entrepreneur as CEO following IPO.

Following the discussion above on the lack of institutional support for nonexecutives, one way to increase effective monitoring of the entrepreneur-founder is to acquire an ownership stake and thus become a principal within the firm. Thus, shareholding by nonexecutive directors will increase the incentive for monitoring and can reduce the ability of the founder-CEO to extract rents by using their entrepreneurial skills, human resource and social networks. Thus, we test the following hypothesis:

Hypothesis 4. The number of nonexecutives owing more than $2 \%$ shareholding in the firm is negatively associated with the probability of the founder-entrepreneur as CEO following IPO. 
The final internal governance mechanism investigated is the ability of the founder-CEO to influence committees and hence decision outcomes. In the executive compensation literature, Core et al (2008) develop the concept of committees influenced by CEO or insider groups that are linked to increased appropriation in the form of self-rewarding behaviour. However, while this is discussed in the entrepreneurship literature it tends to relate to the appropriation of rents within the longer term investment horizon. Thus, we test the following hypothesis:

Hypothesis 5. The presence of "gray" committees, that is, those influenced by the founder, is positively associated with the probability of the founder-entrepreneur as CEO following IPO.

\subsection{External Governance Mechanisms: The Impact of institutions on founder-CEO retention}

Systems of governance are a function of national institutions and provide the legal, political and economic environment in which firms operate. To determine the impact of institutions on the retention of the founder-entrepreneur as CEO following IPO, metrics developed by Kaufman et al (2009) are used. Drakopoulou et al (2002) examined cultural factors that influence networking by entrepreneurs for a sample of eight developed countries. However, this excluded wider institutional differences, which are predicted to have a major role in reducing transactions costs and are the focus of this paper.

One of the important characteristics of the founder-entrepreneur is the ability to create a competitive advantage and hence increase value for the firm. This is frequently based on insider knowledge that be used to appropriate rents to the detriment of minority shareholders. Such agency costs can be reduced if there are high levels of transparency as information flows act as a protection against wholesale expropriation of private benefits of control by the dominant controlling founder at IPO. Therefore, disclosure inherent in anti-corruption legislation that is strictly monitored and enforced is an external governance mechanism. However, in this sample of countries information flows may be restricted and thus we test the following hypothesis:

Hypothesis 6. Control of corruption is positively associated with the probability of the founderentrepreneur as CEO following IPO.

The quality and effectiveness of central government is an essential feature of a progressive society and this require a responsibility to the broader constituency. But if government is influenced by political and social elites the majority interest may conflict with those in control (North, 1989, 1990). Effective government leads to lower transactions costs and make external finance more accessible. However, efficient financial markets are more likely to lead to a market for corporate control and will 
require a professional manager in the role of CEO rather than the founder-entrepreneur following IPO. Thus, we test the following hypothesis:

Hypothesis 7. Effective government is negatively associated with the probability of the founderentrepreneur as CEO following IPO.

Following North's (1990) argument above, the degree of political stability claims that in a developing country context is linked to control by political elites as this enables the appropriation of the private benefits of control and the only recourse is by revolution, which leads to instability (Beck et al, 2000). Thus, in this developing country sample, we test the following hypothesis:

Hypothesis 8. Political stability is negatively associated with the probability of the founderentrepreneur as CEO following IPO.

The ability of the state to enact and enforce sound policies and regulations that promote private sector development is a prerequisite to a viable business environment and economic growth. It requires the avoidance of regulatory capture by firms that wish to direct legal and judicial reform to their own advantage. Controlling owners that wish to secure their private benefits of control can do so more easily if there are state-sponsored monopolies or dominance in certain industries. Dyck and Zingales (2004) find that increased competition that is achieved by effective regulation makes the tunnelling of firm resources by a controlling shareholder more difficult and costly to disguise. Barriers to competition, entrance barriers and constraints related to particular industries are all such regulatory bottlenecks. Thus, we test the following hypothesis:

Hypothesis 9. Regulatory quality is negatively associated with the probability of the founderentrepreneur as CEO following IPO.

Zhang and Wong (2008) find that a sound business environment is partly a function of the quality of the rule of law, particularly with respect to resource and social capital procurement in either a marketorientated or social networking model. However, where the quality of the legal and judicial institutions is poor, there is a greater reliance on social networks to mitigate transactions costs in economic exchange given the degree of mistrust in formal institutions. On the other hand, where the quality of the institutions is high, transactions costs are minimised through professional audit and accounting firms, supported by effective legal systems. Therefore, business environments dominated by social networks are more likely to be associated with a retention of the founder as CEO and we can test the following hypothesis: 
Hypothesis 10. Rule of Law is negatively associated with the probability of the founder-entrepreneur as CEO following IPO.

Finally, following the arguments supporting hypothesis H6, improvements in the institutions that promote information transparency and accountability are more likely to lead to the founder being retained as CEO. This results from protection of minority investors and the acceptance of the tradeoff between more wealth and control and value generation for the firm. Thus, we test the following hypothesis:

H11. Information disclosure (voice \& accountability) is positively associated with probability of THE founder-entrepreneur as CEO following IPO.

\section{Data and Methods}

\subsection{Data}

The dataset was constructed in two stages. In the first stage a list of Initial Primary Offerings (IPOs) from 13 markets in SSA was constructed. The markets included: Cape Verde Islands (Bolsa de Valores de Cabo Verde), Cameroon (Bourse de Douala), Cote d'Ivoire (Bourse Regionale des Valeurs Mobilieres), Malawi, Kenya, Uganda, Tanzania, Zambia, Namibia, Botswana, Mozambique, Mauritius and Ghana for the period 2000 to 2011. Nigeria added for 2002 to 2011, making a total of 167 newly listed firms. The primary source was the national stock exchange websites and these were cross checked with lists from major brokerage houses to ensure accuracy, particularly for Nigeria and Zambia. In the second stage IPO prospectuses were obtained that included data on the number of ordinary shares with single class voting rights, that is preferred stock, convertibles, unit and investment trusts, readmissions, reorganizations and demergers and transfers of listings between main and development boards were excluded. In most cases, flotation prospectuses were obtained from the national stock exchanges or their websites, listings from Nigeria, Malawi and Kenya were were obtained from the Thomson Corporation Perfect Information website, some from the Pangea Stockbrokers (Zambia) and the residual from the African Financials website (African Financials website, 2011). This resulted in a sample of 97 IPOs for which full prospectuses were available. Share prices were from Bloomberg, DataStream and directly from the national stock exchange in Cape Verde and Cameroon. US\$ Exchanges rates were from Bloomberg.

\subsection{Variable measurement}

\subsubsection{CEO founder retention}


The founder-CEO status is a dichotomous variable that equals 1 if the founder is retained as CEO post-IPO and 0 otherwise

\subsubsection{Firm-level governance measures}

\section{Foreign directors}

This is the ratio of foreign directors to total board size. Note that in civil code countries where supervisory boards are common, the total number of directors is the sum of supervisory nonexecutives plus the executive committee appointed to manage day-to-day operations of the firm.

Social elites on the board

This is the ratio of directors with status in the indigenous society associated with membership of the military, government, political, commercial or academic organisation to total board size, with board size calculated as above.

\section{Independent directors}

This is the ratio of nonexecutive directors that have no discernable links, whether these are family, commercial or personal with CEO or dominant insider groups to total board size, with board size calculated as above.

Nonexecutives with ownership $>2 \%$

This is the ratio of nonexecutive directors with ownership in excess of $2 \%$ of total issued and fully paid up share capital of firm to total board size, with board size calculated as above.

\section{Gray Committee}

This is a dichotomous variable that equals 1 if nominally independent board level committees (including remuneration, audit and accounting) falls under influence of CEO and 0 otherwise.

\subsubsection{Measures of institutional quality}

The quality of the institutions is measured using the World Bank Governance Indicators (2011), developed by Kaufman et al (2009). These are a set of six indices that capture aspects of state-level institutions and citizens' perceptions of them. These were first constructed in 1996, then updated every two years until 2002 and annual thereafter. The indicators are compiled from the responses on the quality of governance obtained from 35 data sources in 33 organizations and are drawn from a large sample of firms, citizens and experts in industrial and emerging countries, with added information from institutes, think tanks, non-governmental organizations, and international organizations (Kaufman et al, 2009). The six indicators are constructed using an unobserved 
components methodology (see Kaufman et al (2009), with values ranging from approximately -2.5 to +2.5 and where higher values denote better governance outcomes.

The six governance indices are defined by the World Bank (World Bank Governance website, 2011) as follows:

Voice and Accountability -capturing perceptions of the extent to which a country's citizens are able to participate in selecting their government, as well as freedom of expression, freedom of association, and a free media

Political Stability and Absence of Violence/Terrorism -capturing perceptions of the likelihood that the government will be destabilized or overthrown by unconstitutional or violent means, including politically-motivated violence and terrorism

Government Effectiveness -capturing perceptions of the quality of public services, the quality of the civil service and the degree of its independence from political pressures, the quality of policy formulation and implementation, and the credibility of the government's commitment to such policies

Regulatory Quality -capturing perceptions of the ability of the government to formulate and implement sound policies and regulations that permit and promote private sector development

Rule of Law - capturing perceptions of the extent to which agents have confidence in and abide by the rules of society, and in particular the quality of contract enforcement, property rights, the police, and the courts, as well as the likelihood of crime and violence

Control of Corruption -capturing perceptions of the extent to which public power is exercised for private gain, including both petty and grand forms of corruption, as well as capture of the state by elites and private interests

An aggregate institutional quality index was formed by first rescaling each governance indicator to fit on a scale of between 0 and 10 using equation (1):

$$
\left(\frac{x_{j t}-X_{\text {Min }}}{X_{\text {Min }}-X_{\text {Max }}}\right) * 10
$$

for indicator $\mathrm{i}$ in country $\mathrm{j}$ at time t. These were then summed to create a single governance indicator for each country. 


\subsubsection{Control Variables}

Four groups of controls were included in the model: industry, board, economic determinants and financing arrangements.

Industry controls

Three industry controls are used. Each are dichotomous variables that equal 1 if the IPO firm either operates within an extractive industry (mining, oil, oil services), finance (financial services, banking, real estate), or technology (technology and telecommunications) and 0 otherwise.

Board controls

Size: Board size is defined as the total number of executive and non-executive directors and includes those designated as executive directors in civil code markets where boards are unitary in structure and supervisory in function. Board size follows Jensen (1993) who suggests that larger boards lack cohesiveness and reduces directors' ability to communicate and effectively coordinate corporate strategy thus increasing agency costs. Smaller boards are more likely to be the result of technological and organizational change that leads to reduced costs and corporate downsizing. Thus, board size has an established impact on agency costs and asymmetric information.

Independence: Board independence is defined as the proportion of non-executive directors to total board size. Board independence follows Boyd (1994); Kosnik (1990); Zajac and Westphal (1994) and Conyon and Peck (1998) who claim the role of nonexecutives is to monitor decision-making processes by the executives, thereby protecting minority outsider shareholder interests.

\section{Firm determinants}

Size: The natural logarithm of firm revenues in the pre-IPO year in US\$ was obtained from the IPO prospectus. Firm revenues are long established in the literature as a control for the variation in size as larger firms have greater economic growth opportunities (Rosen (1982); Smith and Watts (1992)).

Age: The natural logarithm of firm age was calculated in years from the date of establishment to the year of the IPO. Younger firms have less established performance track records and as such have greater levels of asymmetric information. Further, the lack of performance history increases the risk associated with future cash flows (Filatotchev and Bishop (2002); Filatotchev et al (2005)).

Financing arrangements 
Business angels: A dichotomous variable that equals 1 if the firm accessed funds from a business angel and 0 otherwise. Angel investors work very closely in partnership with founder-entrepreneurs and share similar longer term investment time horizons. They are prepared to accept a lower rate of return, given their incentives are based on a wish to work with fellow entrepreneurs (Mason and Harrison (1996); Zhang et al (2008)).

Venture capitalists: A dichotomous variable that equals 1 if the firm accessed funds from venture capitalists and 0 otherwise. This differs from business angels as formal private equity/venture capitalists have more formal investment models and are subject to agency conflicts as they are responsible to their own shareholders who are investors in the venture capital funds they are managing (Arthurs et al, 2008).

\subsection{Models and estimation}

Two models are used to test the impact of internal and external governance mechanisms on the retention of the founder-entrepreneur as CEO following IPO. The first focuses on firm board level governance and the aggregate institutional quality index. The dependent variable is dichotomous and thus the appropriate estimating model is a logistic regression. Model 1 is stated:

$$
\begin{aligned}
& \log \frac{P\left(\text { Founder retained }^{C E O_{t}}\right)}{P\left(1-\text { Founder retained } \text { CEO }_{t}\right)}=\alpha \\
&+\beta_{1} \text { Internal Governance }_{i j t-1} \\
&+\beta_{2} \text { Industry Controls }_{i j t-1} \\
&+\beta_{3} \text { Board Controls }_{i j t-1} \\
&+\beta_{4} \text { Firm Characteristics }_{i j t-1} \\
&+\beta_{5}{\text { Aggregate Institutional } \text { Quality }_{i j t-1}} \\
&+\beta_{6} \text { Financing Arrangements }_{i j t-1} \\
&+\varepsilon_{i j t}
\end{aligned}
$$

with subscripts $\mathrm{i}$ for firm level, $\mathrm{j}$ for country level variables and $\mathrm{t}$ for time period and where all variables are defined in the preceding section and aggregate institutional is defined in expression (1).

The second model includes the internal firm governance measures (hypotheses H1 to H5) as controls plus the six institutional quality indices separately (hypotheses H6 to H11) used recursively. Using the internal governance measures as controls allows a comparison with the first model. Model 2 is stated: 


$$
\begin{aligned}
& \log \frac{P\left(\text { Founder retained } C E O_{t}\right)}{P\left(1-\text { Founder retained } C E O_{t}\right)}=\alpha \\
& +\beta_{1} \text { Institutio nal Quality }_{i j t-1} \\
& +\beta_{2} \text { Internal Governance }_{i j t-1} \\
& +\beta_{3} \text { Industry Controls }{ }_{i j t-1} \\
& +\beta_{4} \text { Board Controls }_{i j t-1} \\
& +\beta_{5} \text { Economic Deter min ant }{ }_{i j t-1} \\
& +\beta_{6} \text { Financing Arrangements }_{i j t-1} \\
& +\varepsilon_{i j t}
\end{aligned}
$$

\section{Results}

\subsection{Difference in means tests on firm characteristics}

A series of t-tests were done to investigate whether there are significant differences between firms that retained the founder-entrepreneur as CEO post-IPO and those that appointed a professional manager in this leadership role. Table 1 indicates there are significant differences in internal firm and state-level governance structures associated with founder-led versus non-founder-led firms post-IPO. These results suggest that in this sample of SSA countries, founder-entrepreneurs are more likely to remain in key leadership roles post-IPO in business environments with high institutional quality.

However, when considering internal governance measures, the opposite is true. That is nonfounder led IPO firms have board characterised by a higher proportion of foreign directors, fewer social elites and the CEO has less influence over nominally independent board-level committees. Not surprisingly in this initial analysis, there is a difference between nonexecutives that own in excess of $2 \%$ of issued and fully paid up share capital in founder-led IPO firms compared with non-founder led firms. The tests also suggest that founder-led IPO firms are more likely to be operating in the financial sector or technology and communications have operations in finance and technology industries. There are differences between founder-led and non founder-led IPO firms in terms of the size and independence of the board while they are ten times more likely to have early-stage business angel investor involvement and half as likely to have formal private equity involvement, compared with non-founder led firms, although at low levels of statistical significance. CEO ownership is 34 times greater in founder-led IPO firms (34.03\%) than their non-founder led counterparts (1.02).

\section{Table 1}

\subsection{Impact of internal governance mechanisms on the retention of founder-entrepreneur as CEO following IPO}

The analysis found low levels of correlation between the variables, suggesting multicollinearity is not present and the estimates are efficient. The regression results are in Table 2. There is a large 
negative and statistically significant relationship between ratio of foreign directors and likelihood of founder-entrepreneur as CEO in both models 1 and 6 support hypothesis 1, while there is a positive and significant impact from nonexecutive directors, supporting hypothesis 3 . There is a negative impact from nonexecutives that have an ownership in excess of $2 \%$ of shares issued providing support for hypothesis 4. However, there is no significant influence on founder-entrepreneur retention as CEO from social elites on the board or the existence of a gray committee with undue CEO influence. Thus, hypotheses 2 and 5 are not supported.

The control variables appear to determine founder-entrepreneur retention post-IPO in all 6 models in Table 2. The sector is important, in particular technology and communications, corroborating prior studies that indicate the presence of industry effects. For example, Jain and Tabak (2008) suggest that a strong relationship with these sectors is due to growth and profitability emerging faster and there is less demand for external equity financing, which in turn consolidates concentrated control for the founder and less ownership dilution. Recent evidence from Hearn et al (2009) in a study of Sudan and wider SSA telecommunications sectors and financing provides substantial evidence that this is a rapid growth sector in the region. These results also support those of Jain and Tabak (2008) that find that founder-led IPOs are more likely to be high technology firms. Founderled IPO firms also have smaller boards and lower levels of board independence. In terms of firm characteristics founder-led IPO firms have a negative relationship with size and with age, again supporting Jain and Tabak (2008) in their study of US IPOs. Small, younger firms with less performance history have greater levels of uncertainty and thus retaining the founder-entrepreneur in the pivotal leadership role is reassuring and can enhance value.

Venture capitalist financing has a very large, negative and statistically significant impact on found-entrepreneur retention but the opposite is true of early-stage business angel involvement. These results support Mason and Harrison (1996) and Zhang et al (2008) in their studies on angel finance and Arthurs et al (2008) and Zhang and Wong (2008) in their findings on venture capitalist financing. It is noted that the relationship between founder-led IPO firms and the aggregate institutional quality index is negative although not statistically significance with the exception of model 6. This suggests very weak support for the likelihood that institutional quality has any influence on founder CEOs in post-IPO firms.

\section{Table 2}

\subsection{Impact of external governance mechanisms on the retention of founder-entrepreneur as CEO following IPO}

The results from model 2 are in Table 3. This uses the institutional quality measures that were controls in the previous sector as individual repressors while maintaining the internal firm-level board governance measures (hypotheses 1 to 5) as controls. The results suggest some inconsistencies 
between the institutional quality measures that are introduced recursively in models 7 to 12 and model 13, which includes all six. The estimated coefficients introduced separately are large and negative although control of corruption (hypothesis 6) and voice and accountability (hypothesis 11) are not statistically significant. However, when included together in model 13, there is strong support for hypotheses 6,7 and 10 also a rejection of hypotheses 8 and 9. This is evidence from a very large and positive relationship between founder as CEO and both corruption control and voice and accountability but a correspondingly large and negative relationship between founder as CEO and both government effectiveness and rule of law measures. These results partially support the findings of Zhang and Wong (2008) where rule of law and quality of informational environment are found to be associated with social networks and influence entrepreneurial behaviour.

The controls are similar in size, direction and statistical significance to those in preceding section above. However, the internal governance measures include a large negative and statistically significant relationship for both the share of foreign directors and nonexecutives with ownership in excess of $2 \%$ and a positive one for the share of independent nonexecutives and social elites in model 13. While the relationships between all other controls and founder as CEO are the same in terms of size, direction and statistical significance as those reported above, when including individual institutional quality measures the sizes of the coefficients in all cases is larger and more significant. The explanatory power in models 7 to 13 are up to $10 \%$ higher than in models 1 to 6 , which suggests that external governance mechanisms may be more important than internal ones for this sample of developing and emerging economies and a stable business environment with the rule of law, strong regulations, effective government and accountability is necessary to create a business environment that leads to entrepreneurial activity and economic growth.

\section{Table 3}

\section{Discussion and conclusions}

This study investigates the quality of firm-level governance mechanisms in terms of board characteristics and state-level institutions and their influence on the retention of the founderentrepreneur as CEO following IPO in an agency framework. The sample is unusual as it includes newly listed firms from 14 countries in SSA, where the business environment is weak and there are high levels of corruption, low transparency and little attempt to reduce agency costs resulting from the appropriation of private benefits of control by both founders and social elites that became entrenched following independence. The study has two objectives. The first is to consider internal governance mechanisms in the light of the negotiating power of founder-entrepreneurs and the second is to assess the impact of institutional quality that shape both the business and contracting environment faced by the firm. 
The results indicate that in order to align incentives of multiple principals, given resource dependency and the social networks of founder-entrepreneurs, the founder is more likely to be retained as CEO in firms where there are a larger share of social elites on the board, lower proportions of foreign directors, smaller boards that have fewer nonexecutives and where the share of independent nonexecutives is higher. In support of the ownership concentration hypothesis as a mechanism for incentive alignment the founder is more likely to be retained as CEO where fewer nonexecutives have an ownership stakes in excess of $2 \%$. These characteristics reflect incentive mechanisms for founderentrepreneurs as CEO to align their interests with those of the other principals, given their importance to the firm in terms of value and wealth creation, business angel financing is more closely linked to founders retained as CEO compared with more formalised private equity/venture capital. Business angels in particular are subject to fewer and less complicated multiple agency issues than venture capitalists where the latter are responsible to the shareholders of these managed funds.

External mechanisms, such as high quality institutions, also impact on founder-CEO retention and these may act as substitutions for firm level governance. This is particularly the case in SSA, where there is a wide range of quality in both internal and external governance. We find evidence that improvements in institutional quality measures are most important when addressing information and disclosure. However poor lower levels of rule of law and government effectiveness are found to be associated with founder retention as CEO and this is largely due to these measures being associated with financial market development and access to external finance, which is itself contingent on the quality of external contracting and the legal system. Professional managers may be less well equipped to operate in this environment and founder-entrepreneurs with more social networks may be better able to mitigate transactions costs as they understand the informal markets for resources and finance.

In summary, these results suggest that a major policy imperative in developing countries should be to improve informational transparency and disclosure to stimulate entrepreneurial activity in the formal economic sector while the quality of the judicial and legal systems are more influential in the development of financial markets. Many developing countries face significant liquidity and organisational constraints and these are very costly and a barrier to encouraging entrepreneurial activity in the formal sector. 


\section{References}

African Financial website. 2011. African Financial Statements and Annual Reports. http://www.africanfinancials.com/ Accessed 15 September 2011

Alhorr, H. S., Moore, C. B., and Payne, G. T. 2008. The impact of economic integration on crossborder venture capital investments: Evidence from the European Union. Entrepreneurship Theory and Practice 32 (5): 897-917

Armour, J., and Cumming, D.J. 2006. 'The Legislative Road to Silicon Valley', Oxford Economic Papers 58.

Arthurs, J., Hoskisson, R., Busenitz, L., and Johnson, R. 2008. Managerial agents watching other agents: multiple agency conflicts regarding underpricing in IPO firms. Academy of Management Journal 51: 277-294

Arthurs, J. D., and Busenitz, L. W. 2003. Dynamic capabilities and venture performance: The effects of venture capitalists. Journal of Business Venturing 21(2): 195-215

Audretsch, D. B., Grimm, H. M., and Schuetze, S. 2009. Local Strategies within a European Policy Framework. European Planning Studies 17(3): 463-86

Baysinger, B. D., and Hoskisson, R. E. 1990. Diversification strategy and R\&D intensity in large multiproduct firms. Academy of Management Journal 32: 310-32

Beck, T., Demirgüç-Kunt, A., and Levine, R. 2000. Finance, Inequality and the Poor. World Bank Policy Research papers. World Bank: Washington DC

Bourdieu, P. 1983. 'Forms of capital' in J. C. Richards (ed.). Handbook of Theory and Research for the Sociology of Education, New York: Greenwood Press.

Bouchikhi, H. 1993. A Constructivist Framework for Understanding Entrepreneurship Performance. Organization Studies 14(4): 549-570

Boyd, B. K. 1994. Board control and CEO compensation. Strategic Management Journal 15(5): 335344

Bradford, W. D. 2007. Distinguishing Economically from Legally Formal Firms: Targeting Business Support to Entrepreneurs in South Africa's Townships. Journal of Small Business Management 45(1): 94-115.

Brav, A., and Gompers, P. A. 2003. The Role of Lockups in Initial Public Offerings. Review of Financial Studies 16: 1-29

Bruton, G. D., Filatotchev, I., Chahine, S., and Wright, M. 2009. Governance, Ownership Structure, and Performance of IPO Firms: The Impact of Different Types of Private Equity Investors and Institutional Environments. Strategic Management Journal, forthcoming

Certo, T. S., Covin, J. G., Daily, C. M., and Dalton, D. R. 2001. Wealth and the Effects of Founder Management Among IPO-Stage New Ventures. Strategic Management Journal 22: 641-658

Coff, R. W. 1999. When competitive advantage doesn't lead to performance: The resource-based view and stakeholder bargaining power. Organization Science 10: 119-133 
Coff, R. W., and Lee, P. M. 2003. Insider Trading as a Vehicle to Appropriate Rent from R\&D. Strategic Management Journal 24: 183-190.

Conyon, M. J., and Peck, S. I. 1998. Board Control, Remuneration Committees, and Top Management Compensation. Academy of Management Journal 41: 146-157

Core, J. E., Guay, W., and Larcker, D. F. 2008. The power of the pen and executive compensation. Journal of Financial Economics 88(1): 1-25

Demirgüç-Kunt, A., and Maksimovic, V. 1998. Law, Finance, and Firm Growth. Journal of Finance 53(6): 2107-2137

Doidge, C., Karolyi, A., and Stulz, R. 2007. Why do countries matter so much for corporate governance? Journal of Financial Economics 86: 1-39

Dollinger, M. J. 1995. Entrepreneurship: Strategies and resources. Burr Ridge, IL: Irwin.

Drakopoulou-Dodd, S, Jack, S., and Anderson, A. R. 2002. Scottish entrepreneurial networks in the international context. International Small Business Journal 20(2): 213-219

Dyck, A., and Zingales, L. 2004. Private benefits of control: An international comparison. Journal of Finance 59: 537-600

Filatotchev, I., Wright, M., Chahine, S., and Arberk, M. 2005. Founders' characteristics, venture capital syndication and governance in entrepreneurial IPOs. International Entrepreneurship and Management Journal 1: 419-439

Filatotchev, I., and Bishop, K. 2002. Board composition, share ownership and 'underpricing' of UK IPO firms. Strategic Management Journal 23: 941-955

Gao, N., and Jain, B. A. 2011. Founder CEO management and the long-run investment performance of IPO firms. Journal of Banking \& Finance 35: 1669-1682

Greene, P. G., and Brown, T. E. 1997. Resource Needs and the Dynamic Capitalism Typology. Journal of Business Venturing 12: 161-173.

Harrison, R., Mason, C., and Robson, P. 2010. Determinants of long-distance investing by business angels in the UK. Entrepreneurship \& Regional Development 22: 113-137

Ireland, R. D, Hitt, M. A., and Sirmon, D. G. 2003. Strategic entrepreneurship: The construct and its dimensions. Journal of Management 29: 963-989

Jain, B. A., and Tabak, F. 2008. Factors influencing the choice between founder versus non-founder CEOs for IPO firms. Journal of Business Venturing 23: 21-45

Jeng L.A., and Wells, P. C. 2000. The determinants of venture capital funding: evidence across countries. Journal of Corporate Finance 6(3): 241-289.

Jensen, M. C., and Meckling, W. 1976. Theory of the firm: managerial behavior, agency costs, and ownership structure. Journal of Financial Economics 3: 305-360

Jensen, M. C. 1993. The modern industrial revolution, exit, and the failure of internal control systems. Journal of Finance 48: 831-880 
Joireman S. F. 2001. Inherited Legal Systems and Effective Rule of Law: Africa and the colonial legacy. Journal of Modern African Studies 39(4): 571-596

Joireman S. F. 2006.The Evolution of the Common Law: Legal Development in Kenya and India. Commonwealth and Comparative Politics 21: 190-210

Kaufman, D., Kraay, A., and Mastruzzi, M. 2009. Governance Matters VIII: Governance Indicators for 1996-2008. World Bank Policy Research Unit June 2009

Kosnik, R. 1990. Effects of board demography and director's incentives on corporate greenmail decisions. Academy of Management Journal 33: 129-150

La Porta, R., Lopez-de-Silanes, F., Schliefer, A., and Vishny, R. 2000. Investor protection and corporate governance. Journal of Financial Economics 58: 3-27

La Porta, R., Lopez-de-Silanes, F., Schliefer, A., and Vishny, R. 2002. Investor Protection and Corporate Valuation. Journal of Finance 27(3): 1147-1170

La Porta, R., Lopez-de-Silanes, F., and Shleifer, A. 2008. The Economic Consequences of Legal Origins. Journal of Economic Literature 46: 285-332

Mason, C. M., and Harrison, R. T. 2002. Barriers to investment in the informal venture capital sector. Entrepreneurship \& Regional Development 14: 271-287

Mason, C. M., and Harrison, R. T. 1996. Informal venture capital: a study of the investment process, the post-investment experience and investment performance. Entrepreneurship \& Regional Development 8: 105-125

Maxwell, A. L. and Lévesque, M. 2011. Trustworthiness: A Critical Ingredient for Entrepreneurs Seeking Investors. Entrepreneurship Theory and Practice, forthcoming

Meccheri, N., and Pelloni, G. 2006. Rural Entrepreneurs and Institutional Assistance: An Empirical Study from Mountainous Italy. Entrepreneurship and Regional Development 18(5): 371-392

Megginson, W. 2004. The Financial Economics of Privatization, Oxford University Press, New York, NY

Mitchell, R. K., Smith, J. B, Morse, E. A., Seawright, K. W., Peredo, A. M., and McKenzie, B. 2002. Are entrepreneurial cognitions universal? Assessing entrepreneurial cognitions across cultures. Entrepreneurship: Theory and Practice 26(4): 9-32.

Naudé, W. A., Gries, T., Wood, E., and Meintjies, A. 2008. Regional determinants of entrepreneurial start-ups in a developing country. Entrepreneurship \& Regional Development 20: 111-124

North, D. 1989. Institutions and Economic Growth: An Historical Introduction. World Development 17(9): 1319-1332

North, D. 1990. A Transaction Cost Theory of Politics. Journal of Theoretical Politics 2(4): 355-367

Oxelheim, L. and Randøy, T. 2005. The Anglo-American financial influence on CEO compensation in non-Anglo-American firms. Journal of International Business Studies 36(4): 470-483

Payne, A., Kaj, S., and Pennie, F. 2008. Managing the Co-creation of Value. Academy of Marketing Science 36 (1): 83-96. 
Portes, A. 1998. Social capital: its origins and applications in modern sociology. Annual Review of Sociology 24: 1-25.

Rosen, S. 1982. Authority, Control, and the Distribution of Earnings. Bell Journal of Economics Autumn: 311-323

Rotefoss, B., and Kolvereid, L. 2005. Aspiring, nascent and fledgling entrepreneurs: an investigation of the business start-up process. Entrepreneurship \& Regional Development 17: 109-127

Schumpeter, J. A. 1934. The Theory of Economic Development. Cambridge: Harvard University Press. (New York: Oxford University Press, 1961.) First published in German, 1912

Shane, S., and Cable, D. 2002. Network Ties, Reputation, and the Financing of New Ventures. Management Science 48: 364-381.

Smith, C. W., and Watts, R. L. 1992. The Investment Opportunity Set and Corporate Financing, Dividend, and Compensation Policies. Journal of Financial Economics 32: 263-292

Transparency International. 2011. Corruption Perceptions Index. http://www.transparency.org/ Accessed 15 September 2011

Ucbasaran, D., Wright, M., and Westhead, P. 2003. A Longitudinal Study of Habitual Entrepreneurs: Starters and Acquirers. Entrepreneurship and Regional Development 15(3): 207-228

Westphal, J. D., and Zajac, E. J. 1994. Substance and symbolism in CEOs' long-term incentive plans. Administrative Science Quarterly 39: 367-390

Westphal, J. D., and Zajac, E. J. 1995. Who shall govern? CEO/board power, demographic similarity, and new director selection. Administrative Science Quarterly 40: 60-83

Williamson, O. E. 2000. The new institutional economics: Taking stock, looking ahead. Journal of Economic Literature, XXXVIII: 595-613

Williamson, O. E. 2002. The theory of the firm as governance structure: From choice to contract. Journal of Economic Perspectives 16(3): 171-195

Wright, M., Filatotchev, I., Hoskisson, R. and Peng, M. W. 2005. Strategy research in emerging economies: challenging the conventional wisdom. Journal of Management Studies 42: 1-33

World Bank Governance indicators. 2011. World Bank Governance Indicators. http://info.worldbank.org/governance/wgi/index.asp Accessed 15 September 2011

Zahra, S. A. 1996. Governance, ownership, and corporate entrepreneurship: The moderating impact of industry technological opportunities. Academy of Management Journal 39(6): 1713-1735.

Zhang, J., Souitaris, V., Soh, P-h, and Wong, P-k. 2008. A contingent model of network utilization in early financing of technology ventures. Entrepreneurship Theory \& Practice, 593-613 
Table 1. T-difference in means test for IPO firm characteristics

\begin{tabular}{|c|c|c|c|}
\hline \multirow[b]{2}{*}{ Market } & \multicolumn{3}{|c|}{ Founder CEO vs. Non-Founder CEO Firms } \\
\hline & Founder CEO & $\begin{array}{l}\text { Non-Founder } \\
\text { CEO } \\
\end{array}$ & $\begin{array}{l}\text { Test of difference } \\
\text { statistic }\end{array}$ \\
\hline \multicolumn{4}{|l|}{ External Governance (Institutions) } \\
\hline Index Corruption Control & $0.30(0.23)$ & $0.15(0.25)$ & $1.51 *$ \\
\hline Index Effective Government & $0.39(0.36)$ & $0.18(0.37)$ & $2.25 * *$ \\
\hline Index Political Stability & $0.49(0.43)$ & $0.26(0.51)$ & $2.02 * *$ \\
\hline Index Regulatory Quality & $0.47(0.47)$ & $0.23(0.50)$ & $2.54 \dagger$ \\
\hline Index Rule of Law & $0.41(0.36)$ & $0.20(0.39)$ & $2.04 * *$ \\
\hline Index Voice \& Accountability & $0.55(0.56)$ & $0.24(0.52)$ & $3.20 \dagger \dagger$ \\
\hline Index Aggregate Institutional Quality & $2.62(2.46)$ & $1.26(2.50)$ & $3.64 \dagger \dagger$ \\
\hline \multicolumn{4}{|l|}{ Internal Governance } \\
\hline No. Foreign Directors & $0.42(0.00)$ & $1.17(2.00)$ & 1.18 \\
\hline No. Social Elites on board & $2.26(2.00)$ & $0.81(1.00)$ & $2.26 * *$ \\
\hline No. True Independent Nonexecutives & $1.53(0.00)$ & $0.97(2.00)$ & 0.80 \\
\hline No. Nonexec $>2 \%$ own & $1.00(0.00)$ & $0.05(0.00)$ & $2.73+\dagger$ \\
\hline Gray Committee & $0.84(1.00)$ & $0.16(1.00)$ & $4.26+\dagger$ \\
\hline \multicolumn{4}{|l|}{ Industry } \\
\hline Extractive & $0.05(0.00)$ & $0.06(0.00)$ & 0.09 \\
\hline Finance & $0.53(1.00)$ & $0.18(0.00)$ & $2.29 * *$ \\
\hline Technology/ Telecom. & $0.16(0.00)$ & $0.04(0.00)$ & 0.93 \\
\hline \multicolumn{4}{|l|}{ Governance Variables } \\
\hline Board Size (number) & $7.63(7.00)$ & $3.87(8.00)$ & $2.25 * *$ \\
\hline Board Independence Ratio & $3.15(2.00)$ & $2.00(3.83)$ & $1.41 *$ \\
\hline \multicolumn{4}{|l|}{ Firm Factors } \\
\hline Revenues (US\$ ‘000) & $40,839(12,327)$ & $30,323(32,095)$ & 0.11 \\
\hline Firm Age (years) & $13.16(14.00)$ & $13.60(23.00)$ & 0.07 \\
\hline \multicolumn{4}{|l|}{ Financing Arrangements } \\
\hline Private Equity Involvement & $0.05(0.00)$ & $0.10(0.00)$ & 0.35 \\
\hline Business Angel Involvement & $0.32(0.00)$ & $0.03(0.00)$ & $2.28 * *$ \\
\hline \multicolumn{4}{|l|}{ Ownership } \\
\hline CEO Ownership & $34.03(28.50)$ & $1.02(0.00)$ & $8.96+\dagger$ \\
\hline N (Sample Size) & 19 & 77 & 96 (Total) \\
\hline
\end{tabular}

Notes: $\quad(1) *$ Significant at $10 \%$ confidence level; $* *$ Significant at $5 \%$ confidence level; $\uparrow$ Significant at $1 \%$ confidence level; $\dagger \dagger$ Significant at $0.5 \%$ confidence level

(2) Median values in parentheses 
Table 2. The impact of internal governance factors on founder-entrepreneur retention as CEO following IPO

\begin{tabular}{|c|c|c|c|c|c|c|}
\hline \multirow[b]{3}{*}{ Intercept } & \multicolumn{6}{|c|}{ Likelihood of Founder retained as CEO } \\
\hline & Model 1 & Model 2 & Model 3 & Model 4 & Model 5 & Model 6 \\
\hline & $13.74(2.67) \dagger \dagger$ & $12.17(2.46) \dagger$ & $12.39(2.70) \dagger \dagger$ & $12.49(2.48) \dagger$ & $10.22(1.75)^{* *}$ & $16.37(2.34) \dagger$ \\
\hline \multicolumn{7}{|l|}{ Internal Governance } \\
\hline Ratio Foreign Directors & $-6.16(-2.03)^{* *}$ & & & & & $-7.78(-1.48)^{*}$ \\
\hline Ratio Social Elites on board & & $1.09(0.78)$ & & & & $1.14(0.75)$ \\
\hline Ratio True Independence & & & $1.80(1.28)^{*}$ & & & $3.38(1.50)^{*}$ \\
\hline Ratio Nonexec $>2 \%$ own & & & & $-0.56(-0.24)$ & & $-4.42(-1.33)^{*}$ \\
\hline Gray Committee & & & & & $1.05(0.84)$ & $1.09(0.56)$ \\
\hline \multicolumn{7}{|l|}{ Industry Controls } \\
\hline Extractive Industry & $0.18(0.14)$ & $0.05(0.04)$ & $0.34(0.30)$ & $-0.12(-0.09)$ & $0.11(0.09)$ & $1.10(0.61)$ \\
\hline Finance & $0.17(0.19)$ & $0.54(0.60)$ & $0.52(0.56)$ & $0.61(0.71)$ & $0.51(0.59)$ & $0.56(0.67)$ \\
\hline Technology/ Telecom & $5.89(2.55) \dagger$ & $4.94(2.46) \dagger$ & $4.85(2.71) \dagger \dagger$ & $4.80(2.44) \dagger$ & $4.73(2.34) \dagger$ & $6.61(2.53) \dagger$ \\
\hline \multicolumn{7}{|l|}{ Board Controls } \\
\hline Board Size & $-0.58(-3.62) \dagger \dagger$ & $-0.42(-2.96) \dagger \dagger$ & $-0.39(-2.59) \dagger$ & $-0.42(-2.83) \dagger \dagger$ & $-0.39(-2.49) \dagger$ & $-0.66(-3.09) \dagger \dagger$ \\
\hline Board Ind. Ratio & $-0.45(-1.94)^{* *}$ & $-0.53(-1.90)^{* *}$ & $-0.48(-1.79)^{* *}$ & $-0.47(-1.72)^{* *}$ & $-0.46(-1.76)^{* *}$ & $-0.65(-2.06)^{* *}$ \\
\hline \multicolumn{7}{|l|}{ Economic Determinants } \\
\hline Log (Revenues) & $-0.88(-1.37)^{*}$ & $-1.10(-1.57)^{*}$ & $-1.19(-1.93)^{* *}$ & $-1.06(-1.50)^{*}$ & $-0.99(-1.47)^{*}$ & $-1.02(-2.07)^{* *}$ \\
\hline Log (Firm Age) & $-3.68(-2.52) \dagger$ & $-3.36(-2.15)^{* *}$ & $-3.17(-2.17)^{* *}$ & $-3.42(-2.05)^{* *}$ & $-3.30(-2.29)^{* *}$ & $-4.41(-1.92)^{* *}$ \\
\hline \multicolumn{7}{|l|}{ Institutional Quality } \\
\hline Institutional Quality Index & $-0.37(-0.61)$ & $-0.47(-0.71)$ & $-0.65(-0.95)$ & $-0.56(-0.74)$ & $-0.26(-0.38)$ & $-1.07(-1.28)^{*}$ \\
\hline \multicolumn{7}{|l|}{ Financing Arrangements } \\
\hline PE Involvement & $-6.96(-3.60) \dagger \dagger$ & $-6.49(-3.13) \dagger \dagger$ & $-6.52(-3.34) \dagger \dagger$ & $-6.61(-3.02) \dagger \dagger$ & $-6.79(-3.46) \dagger \dagger$ & $-10.11(-2.54) \dagger$ \\
\hline BA Involvement & $6.35(3.43) \dagger \dagger$ & $6.70(3.13) \dagger \dagger$ & $6.87(3.57) \dagger \dagger$ & $6.71(3.04) \dagger \dagger$ & $6.85(3.56) \dagger \dagger$ & $9.56(2.64) \dagger$ \\
\hline No Obs. $=0$ & 70 & 70 & 70 & 70 & 70 & 70 \\
\hline No Obs. $=1$ & 19 & 19 & 19 & 19 & 19 & 19 \\
\hline No. Obs. & 89 & 89 & 89 & 89 & 89 & 89 \\
\hline LR statistic (prob.) & $54.77(0.00)$ & $49.21(0.00)$ & $52.05(0.00)$ & $49.32(0.00)$ & $49.20(0.00)$ & $58.92(0.00)$ \\
\hline McFadden $\mathrm{R}^{2}$ & 0.5933 & 0.5269 & 0.5343 & 0.5488 & 0.5331 & 0.6384 \\
\hline
\end{tabular}

Notes: $\quad(1){ }^{*} \mathrm{p}<0.10 ; * * \mathrm{p}<0.05 ; \dagger \mathrm{p}<0.01 ; \dagger \dagger \mathrm{p}<0.005$. Z-statistics are in parentheses (2) QML (Huber/White) standard errors \& covariance. 
Table 3. The impact of external governance factors on founder-entrepreneur retention as CEO following IPO

\begin{tabular}{|c|c|c|c|c|c|c|c|}
\hline & \multicolumn{7}{|c|}{ Likelihood of Founder retained as CEO } \\
\hline & Model 7 & Model 8 & Model 9 & Model 10 & Model 11 & Model 12 & Model13 \\
\hline Intercept & $15.50(2.09)^{* *}$ & $17.91(2.15)^{* *}$ & $16.89(2.23)^{* *}$ & $15.97(2.62) \dagger$ & $15.89(2.54) \dagger$ & $13.31(2.11)^{* *}$ & $39.57(3.09) \dagger \dagger$ \\
\hline \multicolumn{8}{|l|}{ External Governance } \\
\hline Index Corruption Control & $-5.81(-0.88)$ & & & & & & $83.72(1.28)^{*}$ \\
\hline Index Effective Government & & $-9.51(-1.28)^{*}$ & & & & & $-114.02(-1.40)^{*}$ \\
\hline Index Political Stability & & & $-4.68(-1.31)^{*}$ & & & & $-6.59(-0.95)$ \\
\hline Index Regulatory Quality & & & & $-7.49(-1.32)^{*}$ & & & $-0.30(-0.02)$ \\
\hline Index Rule of Law & & & & & $-6.07(-1.30)^{*}$ & & $-66.93(-1.43)^{*}$ \\
\hline Index Voice \& Accountability & & & & & & $-2.83(-0.63)$ & $62.19(1.65)^{*}$ \\
\hline \multicolumn{8}{|l|}{ Internal Governance } \\
\hline Ratio Foreign Directors & $-7.14(-1.38)^{*}$ & $-7.68(-1.63)^{*}$ & $-8.12(-1.43)^{*}$ & $-6.75(-1.28)^{*}$ & $-7.70(-1.48)^{*}$ & $-8.38(-1.28)^{*}$ & $-3.69(-1.28)^{*}$ \\
\hline Ratio Social Elites on board & $0.84(0.57)$ & $1.01(0.67)$ & $1.42(0.88)$ & $1.45(0.97)$ & $1.35(0.88)$ & $0.66(0.43)$ & $12.58(2.27)^{* *}$ \\
\hline Ratio True Independence & $2.91(1.40)^{*}$ & $3.62(1.74)^{* *}$ & $3.93(1.74)^{* *}$ & $3.11(1.39)^{*}$ & $3.30(1.41)^{*}$ & $2.55(1.10)$ & $16.32(2.13)^{* *}$ \\
\hline Ratio Nonexec $>2 \%$ own & $-3.99(-1.34)^{*}$ & $-4.89(-1.44)^{*}$ & $-4.73(-1.49)^{*}$ & $-4.16(-1.28)^{*}$ & $-3.97(-1.28)^{*}$ & $-3.46(-0.83)$ & $-9.63(-2.98) \dagger \dagger$ \\
\hline Gray Committee & $1.06(0.56)$ & $1.29(0.67)$ & $0.73(0.34)$ & $1.47(0.80)$ & $0.94(0.48)$ & $1.35(0.77)$ & $1.96(0.81)$ \\
\hline \multicolumn{8}{|l|}{ Industry Controls } \\
\hline Extractive Industry & $0.86(0.44)$ & $1.01(0.57)$ & $1.51(0.82)$ & $0.39(0.22)$ & $1.05(0.57)$ & $1.33(0.75)$ & $1.64(0.95)$ \\
\hline Finance & $0.56(0.72)$ & $0.71(0.85)$ & $0.60(0.68)$ & $0.51(0.60)$ & $0.44(0.54)$ & $0.41(0.44)$ & $1.72(1.29)^{*}$ \\
\hline Technology/ Telecom & $6.39(2.57) \dagger \dagger$ & $6.85(2.52) \dagger$ & $6.83(2.66) \dagger \dagger$ & $6.67(2.47) \dagger$ & $6.37(2.57) \dagger$ & $6.27(2.18)^{* *}$ & $11.77(3.56) \dagger \dagger$ \\
\hline \multicolumn{8}{|l|}{ Board Controls } \\
\hline Board Size & $-0.63(-3.12) \dagger \dagger$ & $-0.70(-2.87) \dagger \dagger$ & $-0.69(-3.21) \dagger \dagger$ & $-0.65(-2.96) \dagger \dagger$ & $-0.62(-3.31) \dagger \dagger$ & $-0.60(-2.53) \dagger$ & $-1.20(-2.87) \dagger \dagger$ \\
\hline Board Ind. Ratio & $-0.66(-1.95) * *$ & $-0.65(-2.06)^{* *}$ & $-0.67(-1.94)^{* *}$ & $-0.62(-2.25)^{* *}$ & $-0.66(-2.13) * *$ & $-0.55(-2.17)^{* *}$ & $-1.19(-2.60) \dagger \dagger$ \\
\hline \multicolumn{8}{|l|}{ Economic Determinants } \\
\hline Log (Revenues) & $-1.02(-1.88)^{* *}$ & $-1.06(-2.17) * *$ & $-1.23(-2.02) * *$ & $-0.87(-2.00) * *$ & $-1.01(-2.00) * *$ & $-0.80(-1.64) * *$ & $-3.86(-2.47) \dagger$ \\
\hline Log (Firm Age) & $-4.53(-2.06) * *$ & $-4.73(-1.94) * *$ & $-4.22(-1.91) * *$ & $-4.29(-1.88) * *$ & $-4.38(-2.02) * *$ & $-4.05(-1.61) * *$ & $-5.23(-1.99) * *$ \\
\hline \multicolumn{8}{|l|}{ Financing Arrangements } \\
\hline PE Involvement & $-9.84(-2.85) \dagger \dagger$ & $-10.73(-2.52) \dagger$ & $-10.31(-2.60) \dagger \dagger$ & $-10.06(-2.50) \dagger$ & $-9.61(-2.70) \dagger \dagger$ & $-9.16(-2.02)^{* *}$ & $-17.44(-2.83) \dagger \dagger$ \\
\hline BA Involvement & $9.36(2.99) \dagger \dagger$ & $10.02(2.66) \dagger \dagger$ & $9.64(2.68) \dagger \dagger$ & $9.53(2.61) \dagger \dagger$ & $9.31(2.83) \dagger \dagger$ & $8.70(2.16) * *$ & $17.77(2.88) \dagger \dagger$ \\
\hline No Obs. $=0$ & 70 & 70 & 70 & 70 & 70 & 70 & 70 \\
\hline No Obs. $=1$ & 19 & 19 & 19 & 19 & 19 & 19 & 19 \\
\hline No. Obs. & 89 & 89 & 89 & 89 & 89 & 89 & 89 \\
\hline LR statistic (prob.) & $58.67(0.00)$ & $58.86(0.00)$ & $59.58(0.00)$ & $58.63(0.00)$ & $59.30(0.00)$ & $57.56(0.00)$ & $69.12(0.00)$ \\
\hline McFadden $\mathrm{R}^{2}$ & 0.6356 & 0.6377 & 0.6455 & 0.6352 & 0.6425 & 0.6236 & 0.7489 \\
\hline
\end{tabular}

Notes: (1) ${ }^{*} \mathrm{p}<0.10 ; * * \mathrm{p}<0.05 ; \dagger \mathrm{p}<0.01 ; \dagger \dagger \mathrm{p}<0.005$. Z-statistics are in parentheses (2) QML (Huber/White) standard errors \& covariance. 